\title{
Pengukuran Waktu Baku untuk Menentukan Produktivitas Karyawan dengan Menggunakan Metode Jam Henti (Studi Kasus CV. Mulia Tata Sejahtera)
}

\author{
Salman Al Faridzi ${ }^{*}$, Kusnadi², Hamdani ${ }^{3}$ \\ 1,2,3 Teknik Industri, Fakultas Teknik, Universitas Singaperbangsa Karawang, Karawang \\ *Koresponden email: salfaridzi047@gmail.com
}

Diterima: 1 Januari 2022

Disetujui: 23 Januari 2022

\begin{abstract}
A company definitely wants maximum profit in its business. High productivity is needed from employees who work in order to get maximum profit. But lately CV. Mulia Tata Sejahtera in meeting the needs of its consumers sometimes experiences delays from the predetermined schedule due to the large number of orders received, it is necessary to calculate the standard time with the downtime method for one of the products, namely the CPM knife. The purpose of this research is to identify working hours and effective working hours so that companies can increase their productivity and determine their daily production. The results of the research carried out obtained that the total standard time in making CPM Knives products was 70.86 minutes and employee productivity in making CPM Knives products was that a worker could complete 6.7 units of CPM Knives in 8 hours/day. Based on the calculation of the standard time it was decided to be 6 units/day so that there was a reduction in working hours for 49.79 minutes from 8 hours/day to 7 hours 10.21 minutes/day.
\end{abstract}

Keywords: productivity, standard time, downtime method, time study, normal time, allowance

\begin{abstract}
Abstrak
Suatu perusahaan pasti menginginkan keuntungan yang maksimal dalam usahanya. Maka diperlukan produktivitas yang tinggi dari karyawan yang bekerja supaya mendapatkan keuntungan yang maksimal. Namun belakangan ini CV. Mulia Tata Sejahtera dalam memenuhi kebutuhan konsumennya terkadang mengalami keterlambatan dari jadwal yang telah ditentukan dikarenakan banyaknya orderan yang diterima, maka perlu dilakukan perhitungan waktu baku dengan metode jam henti terhadap salah satu produk yaitu Pisau CPM. Tujuan pada penelitian kali ini adalah untuk mengidentifikasi jam kerja dan jam kerja efektif agar perusahaan dapat meningkatkan produktivitasnya dan menentukan produksi hariannya. Hasil penelitian yang dilakukan didapatkan total waktu baku dalam pembuatan produk Pisau CPM yaitu sebesar 70,86 menit dan produktivitas karyawan dalam pembuatan produk Pisau CPM adalah seorang tenaga kerja dapat menyelesaikan 6,7 unit produk Pisau CPM dalam waktu 8 jam/hari. Berdasarkan perhitungan waktu baku diputuskan menjadi 6 unit/hari sehingga terjadi pengurangan jam kerja selama 49,79 menit yang sebelumnya 8 jam/hari menjadi 7 jam 10,21 menit/hari.
\end{abstract}

Kata Kunci: produktivitas, waktu baku, metode jam henti, waktu studi, waktu normal, allowance

\section{Pendahuluan}

Pada masa perkembangan teknologi industri 4.0 yang berkembang dengan cepat seperti sekarang, dan juga seiring dengan tingginya dari tingkat permintaan konsumen terhadap kebutuhan suatu produk, maka dapat memicu atau munculnya persaingan yang ketat di beberapa perusahaan industri khususnya dibidang manufaktur. Untuk mempercepat laju produksi diperlukan peran dari berbagai macam teknologi yang digunakan. Didalam sistem produksi waktu kerja ialah faktor yang penting dan perlu diperhatikan [1]. Selain itu keuntungan merupakan salah satu tujuan utama perusahaan dalam menjalankan bisnisnya dimana untuk mengoptimalkannya dengan cara memperbaiki masalah yang ada dalam perusahaan tersebut guna memberikan laba yang optimal [2]. Suatu perusahaan pasti menginginkan keuntungan yang maksimal maka diperlukan produktivitas yang tinggi dari karyawan yang bekerja. Faktor penting yang memiliki pengaruh terhadap keberlangsungan perusahaan salah satunya adalah produktivitas [3]. Dalam produktivitas tenaga kerja, terdapat hubungan antara hasil pekerjaan dengan waktu yang digunakan. Sehingga dalam praktiknya akan menghasilkan perbandingan antara output yang didapat dengan banyaknya waktu yang dibutuhkan oleh tenaga kerja. Dari hal itu, agar tercapainya sistem produksi yang baik maka waktu baku sangat diperlukan atau dibutuhkan saat ini. Hal ini dikarenakan suatu pekerjaan dikatakan efisien ketika dapat 
diselesaikan dengan waktu baku paling sedikit. Waktu dari seorang pekerja dalam menyelesaikan pekerjaan dengan suatu metode tertentu serta pada kondisi terbaik saat itu hal tersebut merupakan pengertian dari waktu baku [4].

CV. Mulia Tata Sejahtera adalah suatu UMKM atau badan bisnis yang bergerak dalam bidang manufaktur logam maupun non logam yang memproses sebuah material dari bahan mentah menjadi suatu produk jadi dengan sistem make to order. Namun belakangan ini CV. Mulia Tata Sejahtera dalam memenuhi kebutuhan konsumennya terkadang suka mengalami keterlambatan dari jadwal yang telah ditentukan dikarenakan banyaknya orderan yang diterima terutama pada salah satu produknya yaitu Pisau CPM, Hal ini disebabkan jam kerja yang tidak efisien dan efektif karena karyawan tidak mengerjakan tugasnya. Selain hal tersebut, terdapat faktor lain seperti lingkungan kerja yang kurang nyaman dan aman serta minimnya peralatan yang dapat mempengaruhi produktivitas dan menyebabkan kebingungan dalam proses pembuatan. Serta belum ada pengukuran waktu kerja atau waktu baku dalam menyelesaikan pembuatan Pisau CPM supaya dapat mengetahui produktivitasnya. Pada praktiknya, proses produksi dari pisau CPM dilakukan oleh beberapa karyawan. Namun pada proses yang berlangsung, produksi pisau CPM dilakukan oleh satu orang karyawan secara kontinu, sehingga dari hal ini pengukuran waktu baku dengan jam henti dapat dilakukan.

Dalam usaha untuk menetapkan waktu baku pada suatu proses pekerjaan, pengukuran waktu kerja memiliki peran dan hubungan dalam penetapan tersebut [5]. Terdapat dua metode dalam melakukan pengukuran waktu kerja, yaitu langsung dan tidak langsung. Perbedaan dua metode tersebut terletak pada posisi pengamat, yaitu pada pengukuran langsung dilakukan dengan pengamat berada ditempat dan secara langsung melakukan pengukuran pada operator. Sementara tidak langsung dilakukan perhitungan waktu oleh pengamat yang tidak harus berada ditempat pengamatan [6].

Melihat kondisi tersebut masih belum terdapat analisis dan pengukuran kerja pada perusahaan. Sehingga dirasa perlu dilakukan pengukuran kinerja pada pekerja dengan waktu baku. Sehingga dapat diketahui kualitas kerja karyawan dan menentukan alternatif tindakan untuk mendapatkan hasil yang lebih produktif bagi perusahaan. Digunakan metode jam henti untuk mengukur kinerja karyawan pada proses pengecekan, metode ini adalah suatu teknik untuk mengamati kualitas kerja karyawan dalam melakukan pekerjaannya [7]. Menurut penelitian Ayuningtyas penggunaan metode jam henti diterapkan pada perhitungan waktu normal dan waktu baku dengan terlebih dahulu mengidentifikasikan waktu siklusnya [8]. Untuk sebuah perusahaan produsen data waktu baku digunakan untuk mempermudah dalam pemilihan sasaran produksi [9]. Menurut penelitian Lukodono dan Ulfa dalam proses produksi, sangat penting untuk ditentukan waktu standarnya terlebih lagi pada proses yang masih menggunakan tenaga manusia [10]. Adapun kebaharuan penelitian ini yaitu dengan menambahkan perhitungan aspek produktivitas tenaga kerja. Sehingga dari hasil pengukuran waktu kerja dapat diketahui produktivitas tenaga kerja yang digunakan.

Berdasarkan uraian permasalahan diatas, maka pengukuran waktu baku dengan menggunakan metode jam henti dianggap perlu untuk menganalisis produktivitas karyawan pada proses produksi pisau CPM. Adapun penelitian ini ditujukan untuk mengidentifikasi jam kerja dan jam kerja efektif agar perusahaan dapat meningkatkan produktivitasnya dan menentukan produksi hariannya.

\section{Metode Penelitian}

Objek pada penelitian ini yaitu CV. Mulia Tata Sejahtera pada tanggal 27 Februari 2021. Penelitian ini berjenis penelitian deskriptif (descriptive research). Dengan kata lain, merupakan penyelidikan yang secara sistematis memecahkan masalah yang ada saat ini, berdasarkan fakta berdasarkan data yang ada pakai metode Jam Henti. Penelitian ini ditujukan untuk mengukur waktu standar yang digunakan karyawan dalam mengerjakan produksi pisau CPM. Selain itu, jam kerja normal karyawan juga diukur untuk mengetahui produktivitas karyawan, sehingga mengatasi masalah keterlambatan kerja.

Variabel pada penelitian ini adalah waktu siklus dalam menyelesaikan pekerjaan pembuatan pisau CPM. Proses pengolahan data pada penelitian ini dilakukan dalam beberapa tahap pengukuran seperti berikut:

a. Mengukur rata-rata waktu siklus pada setiap komponen pekerjaan.

$$
\bar{X}=\frac{\sum X i}{N}
$$

b. Data yang didapatkan kemudian dilakukan uji keseragaman data untuk mengidentifikasi dan mengetahui batas kontrol data baik atas ataupun bawah.

$$
\begin{array}{ll}
\mathrm{BKA} & =\bar{X}+\mathrm{k} . \delta \\
\mathrm{BKB} & =\bar{X}-\mathrm{k} . \delta
\end{array}
$$




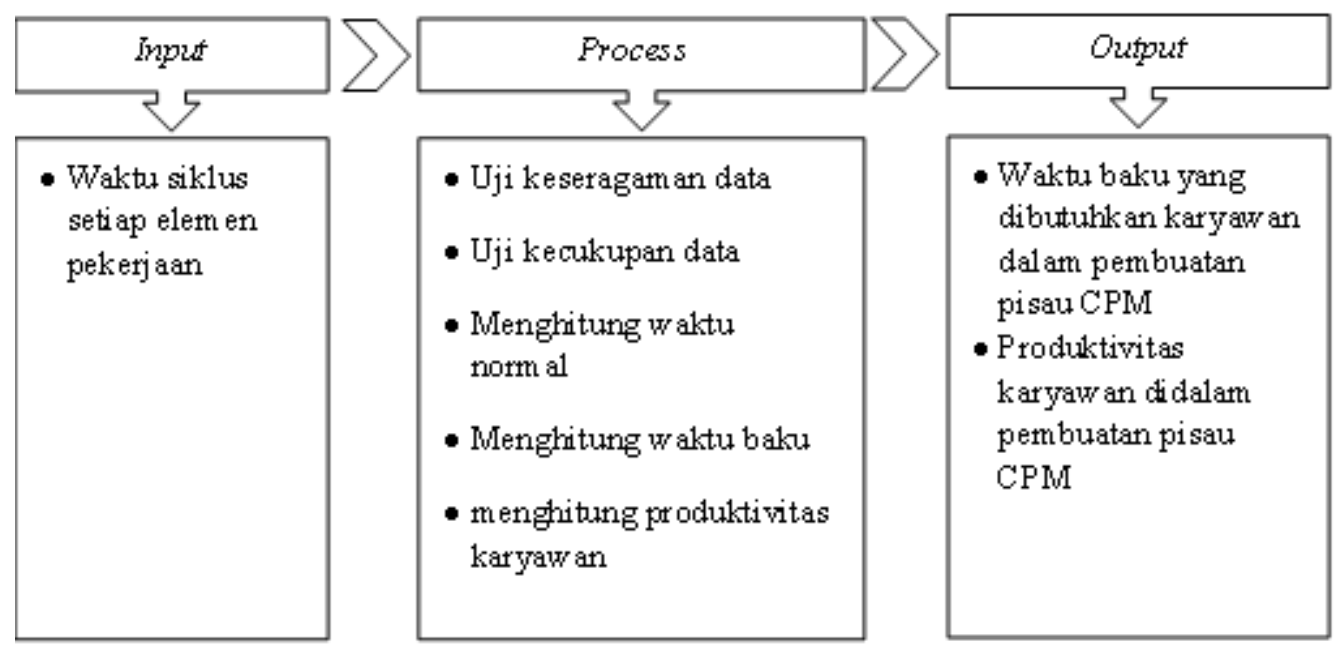

Gambar 1. Kerangka berpikir penelitian Sumber: Data penelitian (2021)

c. Melakukan uji kecukupan data,

$$
N=\left[\frac{\frac{k}{s} \sqrt{N \cdot \sum x i^{2}-\left(\sum x i\right)^{2}}}{\sum x i}\right]
$$

d. Melakukan pengukuran waktu normal (Wn),

$W n=W s \times p$

e. Melakukan pengukuran waktu baku (Wb).

$W B=(W S \times R F) \times \frac{100 \%}{100 \%-\text { Allowance }}$

Setelah selesai kemudian dilakukan penghitungan hasil produksi yang kemudian dilakukan penghitungan produktivitas pada tenaga kerja. Hasil akhir pada penelitian ini diperuntukkan dalam menentukan waktu standar yang diperlukan seorang karyawan dalam menyelesaikan pekerjaan produksi pisau CPM serta menganalisis produktivitas tenaga kerja tersebut.

\section{Hasil dan Pembahasan}

\section{Pengumpulan Data}

Pengumpulan data dalam penelitian ini adalah data yang dikumpulkan secara langsung saat mengamati di CV. Mulia Tata Sejahtera. Teknik pengambilan data yang digunakan dalam penelitian ini dapat dibagi menjadi dua kategori:

a. Sumber Data

Data yang digunakan pada penelitian ini berasal dari salah satu produsen yang memproduksi berbagai jenis custom product di Kosambi yaitu CV. Mulia Tata Sejahtera. Selain itu, data diambil dari studi literatur untuk melengkapi analisis data sekunder yang dikumpulkan di lokasi penelitian. Teknik pengambilan data adalah mengukur waktu penyelesaian pembuatan produk pisau CPM.

b. Jenis Data

1) Data Primer

Data primer pada penelitian ini didapatkan dengan mengamati secara langsung pada objek penelitian yang berupa waktu kerja yang dibutuhkan pada setiap komponen pekerjaan dalam proses produksi pisau CPM.

2) Data Sekunder

Data sekunder didapatkan dari sumber kedua yaitu perusahaan yang berupa data produksi serta jumlah pekerja yang dimiliki perusahaan.

Dalam penelitian ini, dilakukan 20 kali pengukuran pada proses pembuatan pisau CPM untuk dua pekerja dilakukan dengan menggunakan stopwatch, yang memproses data dalam beberapa langkah selama waktu standar. Adapun hasil yang didapatkan pada pengukuran tersebut seperti pada Tabel 1. 
Tabel 1. Hasil pengukuran waktu kerja tiap komponen proses pekerjaan produk pisau CPM

\begin{tabular}{cccc}
\hline No. & Proses Mesin Bubut & Proses Mesin Milling & Proses Mesin Grinding \\
\hline 1. & 11.49 & 28.57 & 10.17 \\
2. & 13.98 & 28.11 & 12.53 \\
3. & 13.81 & 27.90 & 10.21 \\
4. & 13.57 & 26.85 & 10.45 \\
5. & 11.91 & 25.32 & 12.58 \\
6. & 14.46 & 25.88 & 11.21 \\
7. & 14.52 & 27.07 & 12.15 \\
8. & 14.52 & 28.34 & 11.65 \\
9. & 12.37 & 27.65 & 10.36 \\
10. & 13.71 & 25.88 & 11.17 \\
11. & 12.47 & 28.57 & 10.65 \\
12 & 10.33 & 27.43 & 10.47 \\
13. & 14.63 & 29.48 & 11.14 \\
14. & 12.21 & 25.13 & 10.83 \\
15. & 11.71 & 27.15 & 11.83 \\
16 & 12.82 & 28.79 & 11.43 \\
17. & 14.22 & 25.51 & 12.19 \\
18. & 10.55 & 29.22 & 12.29 \\
19. & 11.38 & 26.16 & 10.40 \\
20. & 13.45 & 27.52 & 11.93 \\
\hline
\end{tabular}

Sumber: CV. Mulia Tata Sejahtera (2021)

\section{Pengolahan Data}

a. Uji Keseragaman Data

Uji keseragaman data dilakukan untuk melihat apakah hasil pengukuran waktu yang dilakukan cukup seragam [11]. Pengujian keseragaman ini dilakukan dengan tujuan untuk mengetahui dan memastikan bahwa data yang digunakan sudah seragam. Keseragaman data ini dapat dilihat dan ditandai dengan data tidak ada yang keluar dari batas kontrol yang sudah ditentukan [12]. Pada tahap pengujian keseragaman ini dilakukan pada setiap komponen pekerjaan pada setiap stasiun kerja, dimana pada tahap ini digunakan tingkat kepercayaan $95 \%$ dan tingkat ketelitian $5 \%$.

1) Menentukan waktu siklus rata-rata pada proses di mesin bubut.

$$
\begin{aligned}
\bar{X} & =\frac{\sum X i}{N} \\
& =\frac{11.49+13.98+13.81+13.57+11.91+\cdots+13.45}{20} \\
& =12.91 \text { menit }
\end{aligned}
$$

2) Menghitung standar deviasi

$$
\begin{aligned}
\sigma & =\sqrt{\frac{\sum(x i-\bar{x})^{2}}{(N-1)}} \\
& =\sqrt{\frac{\sum(11.49-12.91)^{2}+(13.98-12.91)^{2}+(13.81-12.91)^{2}+\ldots+(13.45-12.91)^{2}}{(20-1)}} \\
& =\sqrt{1,870} \\
& =1,37
\end{aligned}
$$

3) Menentukan BKA dan BKB

$$
\begin{aligned}
\mathrm{BKA} & =\bar{X}+2 . \sigma \\
& =12,91+2(1,37) \\
& =15,64 \\
\mathrm{BKB} & =\bar{X}-2 . \sigma \\
& =12,91-2(1,37) \\
& =10,18
\end{aligned}
$$

Setelah dilakukan perhitungan uji keseragaman data pada tiap proses pekerjaan di masing-masing mesin atau stasiun kerja maka didapatkan hasil keseluruhan dari perhitungan uji keseragaman data dan grafik Peta Kendali proses yang menunjukkan Batas Kendali Atas (BKA) dan juga Batas Kendali Bawah (BKB) yang ditunjukkan pada Tabel 2 dan Gambar 2. 
Tabel 2. Hasil pengujian keseragaman data tiap stasiun kerja

\begin{tabular}{lccc}
\hline $\begin{array}{l}\text { Mesin/Stasiun } \\
\text { Kerja }\end{array}$ & BKA & BKB & Rata-Rata \\
\hline Mesin Bubut & 15,64 & 10,18 & 12,91 \\
Mesin Milling & 29,99 & 24,67 & 27,33 \\
Mesin Grinding & 12,92 & 9,65 & 11,28 \\
\hline
\end{tabular}

Sumber: Hasil pengolahan data (2021)

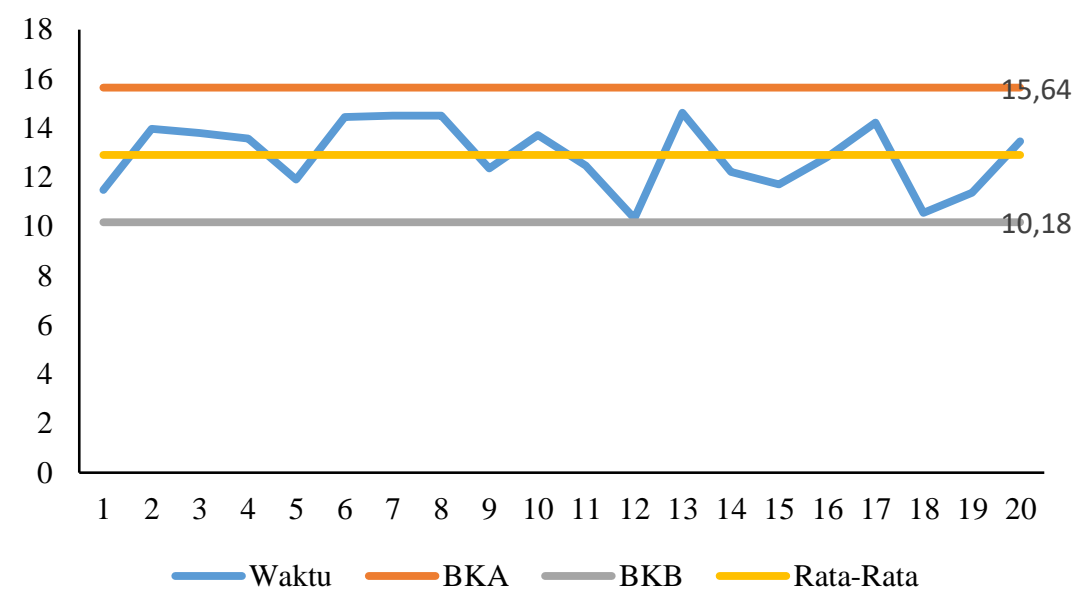

Gambar 2. Grafik peta kendali proses pada mesin bubut Sumber: Hasil pengolahan data (2021)

Berdasarkan hasil yang didapatkan pada Gambar 2 dapat diketahui bahwa data masih berada dalam batas kendali. Hal ini berarti data sudah berada dalam kondisi seragam karena tidak ada data waktu yang keluar dari BKA dan BKB. Agar data tetap konsisten. Perhitungan uji keseragaman data untuk tahap proses selanjutnya adalah sama, tetapi tentu saja waktu dan hasil pengukurannya berbeda.

b. Uji Kecukupan Data

Setelah data diuji dengan keseragaman data dan didapatkan hasil data yang seragam, selanjutnya dilakukan pengujian kecukupan data. Adapun hasil pada pengujian kecukupan data dilakukan pada setiap stasiun kerja dan didapatkan hasil seperti pada Tabel 3.

Tabel 3. Hasil pengujian kecukupan data setiap stasiun kerja

\begin{tabular}{clccc}
\hline No. & \multicolumn{1}{c}{ Proses Pekerjaan } & N & N' & Keterangan \\
\hline 1. & Proses Pekerjaan di Mesin Bubut & 20 & 17,06 & Cukup \\
2. & Proses Pekerjaan di Mesin Milling & 20 & 3,6 & Cukup \\
3. & Proses Pekerjaan di Mesin Grinding & 20 & 6,1 & Cukup \\
\hline
\end{tabular}

Sumber: Hasil pengolahan data (2021)

\section{c. Rating Factor}

Setelah data dianggap cukup, langkah selanjutnya adalah menambahkan faktor penyesuaian atau penilaian menurut metode Westinghouse (keterampilan, upaya, kondisi kerja, konsistensi). Faktor penyesuaian ini dilakukan untuk menilai kondisi pada setiap stasiun kerja berdasarkan metode Westinghouse tersebut. Pemberian nilai pada setiap faktor didasarkan pada ukuran pengamatan dari peneliti. Adapun hasil pada faktor penyesuaian setiap stasiun kerja tersebut ditunjukkan pada Tabel 4.

Tabel 4. Rating factor tiap stasiun kerja

\begin{tabular}{|c|c|c|c|}
\hline Faktor & Kelas & Lambang & Penyesuaian \\
\hline Keterampilan & Excellent Skill & B1 & 0,11 \\
\hline Usaha & Good & $\mathrm{C} 1$ & 0,05 \\
\hline Kondisi Kerja & Good & $\mathrm{C}$ & 0,02 \\
\hline Konsistensi & Avarage & D & 0 \\
\hline \multicolumn{3}{|c|}{ Total } & 0,8 \\
\hline
\end{tabular}

Sumber: Hasil pengolahan data (2021) 


\section{d. Waktu Normal}

Waktu normal adalah waktu kerja yang dibutuhkan dalam menyelesaikan pekerjaan dengan mempertimbangkan faktor penyesuaian. Waktu normal ini didapatkan berdasarkan hasil perkalian antara faktor penyesuaian dengan nilai rata-rata waktu siklus [13]. Adapun hasil yang didapatkan untuk pengukuran waktu normal setiap proses pekerjaan seperti ditunjukkan pada Tabel 5.

Tabel 5. Hasil perhitungan waktu normal setiap stasiun kerja

\begin{tabular}{clccc}
\hline No. & Proses Pekerjaan & $\begin{array}{c}\text { Waktu Siklus } \\
\text { (Menit) }\end{array}$ & $\begin{array}{c}\text { Waktu Normal } \\
\text { (Menit) }\end{array}$ & $\begin{array}{c}\text { Waktu Baku } \\
\text { (Menit) }\end{array}$ \\
\hline 1. & Proses Pekerjaan di Mesin Bubut & 12,91 & 15,23 & 17,82 \\
2. & Proses Pekerjaan di Mesin Milling & 27,3 & 32,25 & 37,73 \\
3. & Proses Pekerjaan di Mesin Grinding & 11,28 & 13,31 & 15,31 \\
\hline \multicolumn{6}{c}{ Total } & 51,52 & 60,79 & 70,86 \\
\hline
\end{tabular}

Sumber: Hasil pengolahan data (2021)

\section{e. Faktor Kelonggaran}

Tahap selanjutnya dalam proses pengukuran waktu baku ini adalah dengan menentukan faktor kelonggaran. Faktor kelonggaran ini merupakan sebuah faktor kesenggangan yang harus diberikan pada waktu kerja seorang karyawan. [14]. Kelonggaran ini diberikan untuk memperhitungkan hal diluar pekerjaan utama namun memiliki pengaruh seperti kebutuhan pribadi karyawan, proses istirahat atau penghilang rasa lelah, serta halangan yang tidak dapat dihilangkan [15]. Penentuan faktor kelonggaran ini sama seperti tahap sebelumnya juga dilakukan pada setiap komponen pekerjaan stasiun kerja. Penentuan faktor kelonggaran diberikan dalam bentuk persentase yang didasarkan pada penilaian pengamat. Pemberian nilai setiap komponen ini tidak serta-merta spontan, namun dinilai berdasarkan pekerjaan dan melalui pertimbangan dengan karyawan yang melakukan pekerjaannya. Adapun hasil faktor kelonggaran pada setiap komponen stasiun kerja seperti ditunjukkan pada Tabel 6.

Tabel 6. Hasil faktor kelonggaran setiap stasiun kerja

\begin{tabular}{cc}
\hline \multicolumn{1}{c}{ Faktor Kelonggaran } & Total Kelonggaran \% \\
\hline Faktor Kelonggaran Pada Mesin Bubut & 17 \\
Faktor Kelonggaran Pada Mesin Milling & 17 \\
Faktor Kelonggaran Pada Mesin Grinding & 15 \\
\hline Total & 49 \\
\hline Sumber: Hasil pengolahan data (2021)
\end{tabular}

f. Menentukan Waktu Baku

Hasil perhitungan waktu baku total dalam pembuatan produk pisau CPM berdasarkan perhitungan waktu baku dan faktor toleransi untuk setiap tahapan pekerjaan yang terdapat pada Tabel 7.

Tabel 7. Rekapitulasi hasil perhitungan waktu baku setiap proses pekerjaan pada mesin

\begin{tabular}{clccc}
\hline No & Tahapan Pekerjaan & $\begin{array}{c}\text { Waktu Normal } \\
\text { (Menit) }\end{array}$ & $\begin{array}{c}\text { Total Faktor } \\
\text { Kelonggaran }\end{array}$ & $\begin{array}{c}\text { Waktu Baku } \\
\text { (Menit) }\end{array}$ \\
\hline 1 & Proses Pekerjaan di Mesin Bubut & 15.23 & 0.17 & 17.82 \\
2 & Proses Pekerjaan di Mesin Milling & 32.25 & 0.17 & 37.73 \\
3 & Proses Pekerjaan di Mesin Grinding & 13.31 & 0.15 & 15.31 \\
\hline \multicolumn{5}{c}{ Total } \\
\multicolumn{5}{c}{ Sumber: Hasil pengolahan data (2021) }
\end{tabular}

Berdasarkan hasil yang didapatkan pada Tabel 7 dapat diketahui waktu baku dalam memproduksi pisau CPM sebesar 70,86 menit. Waktu tersebut merupakan kumulatif dari setiap proses yang dilalui seperti proses mesin bubut, mesin milling, dan mesin grinding. Sehingga pada akhirnya didapatkan waktu baku dalam memproduksi satu pcs pisau CPM memerlukan waktu selama 70, 86 menit.

\section{g. Produktivitas Tenaga Kerja}

Produktivitas tenaga kerja adalah tingkat keunggulan dan pengendalian tingkat keunggulan yang diharapkan dapat memenuhi permintaan konsumen [16]. Saat menghitung produktivitas, output dasar bukanlah hasil yang didapatkan dengan lembur, tetapi output yang dihasilkan oleh pekerja selama jam kerja normal. Metode pengukuran tersebut dapat digunakan untuk mengukur waktu kerja serta diartikan 
sebagai jumlah pekerjaan yang mampu dikerjakan seorang pekerja dalam satuan waktu. Waktu yang dibutuhkan berasal dari nilai waktu standar untuk setiap langkah kerja yang dilakukan dalam pembuatan produk pisau CPM. Adapun hasil pengukuran produktivitas tenaga kerja ditetapkan jumlah jam kerja dalam sehari adalah 8 jam dan didapatkan seperti berikut:

$\begin{aligned} \text { Produktivitas Tenaga Kerja } & =\frac{8 \times 60=480}{71,13} \\ & =\frac{480}{71,13} \\ & =6,7 \text { unit/hari }\end{aligned}$

Dari hasil tersebut dapat disimpulkan bahwa dalam satu hari kerja seorang tenaga kerja di perusahaan CV. Mulia Tata Sejahtera dapat menyelesaikan 6,7 unit produk pisau CPM per hari. Dari perhitungan produktivitas karyawan, diputuskan untuk memproduksi 6 unit per karyawan per hari. Jam kerja akan dikurangi dari 8 jam sehari menjadi 7 jam 10,21 menit dari hasil perhitungan berikut:

Pengurangan jam kerja $\quad=0,7$ unit $\mathrm{x} 70,86$ waktu baku

$$
=49,79 \text { menit }
$$

Melalui pengukuran yang telah dilakukan dapat diketahui ketika perusahaan dapat mengetahui waktu baku dan produktivitas tenaga kerja, maka dapat dihitung dan direncanakan untuk pesanan yang masuk. Dari hal tersebut perusahaan dapat menentukan tindakan ketika pesanan masuk ataupun kebutuhan konsumen meningkat agar tidak lagi terjadi penumpukan pekerjaan yang akhirnya menimbulkan keterlambatan dalam memproduksi Pisau CPM. Dengan demikian, proses produksi dapat lebih terkendali dan permintaan konsumen dapat terpenuhi tepat waktu sesuai dengan kesepakatan yang telah ditentukan.

\section{Kesimpulan}

Berdasarkan uraian permasalahan dan pembahasan yang dilakukan dapat diketahui lama waktu baku yang diperlukan dalam proses produksi Pisau CPM dari CV. Mulia Tata Sejahtera sebesar 70,86 menit. Lama waktu tersebut didapatkan dari kumulatif waktu baku pada setiap proses stasiun kerja yang dilalui pada proses produksi Pisau CPM tersebut. Selain itu diketahui juga karyawan dalam satu hari kerja seorang tenaga kerja di perusahaan CV. Mulia Tata Sejahtera dapat menyelesaikan 6,7 unit produk pisau CPM per hari. Dari perhitungan produktivitas karyawan, diputuskan untuk memproduksi 6 unit per karyawan per hari. Jam kerja akan dikurangi dari 8 jam sehari menjadi 7 jam 10,21 menit. Dengan penentuan waktu baku dan produktivitas karyawan tersebut dapat bermanfaat bagi perusahaan diantaranya dapat melakukan perencanaan produksi harian, serta menentukan pesanan yang ditangani sehingga tidak lagi terjadi keterlambatan sehingga dapat meningkatkan kepuasan pelanggan.

Untuk penelitian yang akan datang terkait produktivitas dapat dilakukan dengan menggunakan metode lain dan membandingkannya. Hal ini bertujuan untuk mendapatkan hasil yang terbaik dari hasil pengukuran waktu baku untuk menentukan produktivitas.

\section{Referensi}

[1] M. H. M. Wildan Ghozali, "Pengukuran Waktu Baku Proses Finishing Line Volpak Produksi Lannate Sp 25 Gram Philipina Guna Meningkatkan Produktivitas (PT . Dupont Agricultural Products Indonesia)," J. Knowl. Ind. Eng., vol. 3, no. 3, pp. 31-39, 2016.

[2] A. Gunawan, K. Kusnadi, and H. Hamdani, "Analisis Produktivitas Tenaga Kerja dengan Metode Marvin E. Mundel pada CV. Mulia Tata Sejahtera," J. Serambi Eng., vol. 6, no. 3, pp. 2135-2143, 2021.

[3] S. Al Faritsy, A. Z., \& Suseno, "Peningkatan Produktivitas Perusahaan dengan Menggunakan Metode Six Sigma, Lean dan Kaizen,” J. Tek. Ind., vol. 10, no. (2), pp. 103-116, 2015.

[4] Daryanto, Manajemen Produksi. Bandung: Satu Nusa, 2012.

[5] N. V. Febriana, E. R. Lestari, and S. Anggarini, "Analisis Pengukuran Waktu Kerja Dengan Metode Pengukuran Kerja Secara Tidak Langsung Pada Bagian Pengemasan di PT Japfa Comfeed Indonesia Tbk," J. Ind., vol. 4, no. 1, pp. 66-73, 2015.

[6] M. Rahayu and S. Juhara, "Pengukuran Waktu Baku Perakitan Pena Dengan Menggunakan Waktu Jam Henti Saat Praktikum Analisa Perancangan Kerja," Unistek, vol. 7, no. 2, pp. 93-97, 2020.

[7] M. A. Bora, Larisang, and T. Kamariah, "Penentuan Pengukuran Waktu Baku Pemeriksaan Wire 
Connector Pada Out Going Check Menggunakan Metode Jam Henti,” J. Ind. Kreat., vol. 4, no. 01, pp. 57-62, 2020.

[8] R. S. Ayuningtyas Nasir Widha; Efranto, Remba Yanuar, "Analisis Peningkatan Produktivitas dan Efisiensi Kerja Dengan Penerapan Kaizen(Studi Kasus pada PT Beiersdorf Indonesia PC Malang)," J. Rekayasa dan Manaj. Sist. Ind., no. Vol 2, No 1 (2014), pp. p175-186, 2014.

[9] I. Sukania and T. Gunawan, "Analisa Waktu Baku Elemen Kerja pada Pekerjaan Penempelan Cutting Stiker di CV Cahaya Thesani," J. Energi Dan Manufaktur, vol. 7, no. 2, pp. 155-162, 2014.

[10] R. P. Lukodono and S. K. Ulfa, "Determination of Standard Time in Packaging Processing Using Stopwatch Time Study To Find Output Standard,” J. Eng. Manag. Ind. Syst., vol. 5, no. 2, pp. 8794, 2018.

[11] L. Gozali, Andres, and Feriyatis, "Penentuan Jumlah Tenaga Kerja dengan Metode Keseimbangan Lini pada Divisi Plastic Painting PT. XYZ,” J. Ilm. Tek. Ind., vol. 3, no. 1, pp. 10-17, 2015.

[12] J. Manajemen, S. I. Kaban, R. D. Astuti, and E. Pujiyanto, "Perancangan Alat Pemotong Label untuk Meminimasi Gerakan Repetitive Pekerja di Industri Jago Jaya Shuttlecock Surakarta," J. Manaj. Tek. Ind. - Produksi, vol. 22, no. 1, 2021.

[13] Y. D. Regent M, "Usulan Penentuan Waktu Baku Proses Racking Produk Amplimesh Dengan Metode Jam Henti Pada Departemen Powder Coating," J. Tek., vol. 7, no. 2, 2019.

[14] O. Veza, "Analisis Waktu Standar Pelayanan Dan Produktivitas Pegawai Menggunakan Metode Work Sampling," J. Ind. Kreat., vol. 1, no. 01, p. 9, 2017.

[15] M. I. Tarigan, "Pengukuran standar waktu kerja untuk menentukan jumlah tenaga kerja optimal," Manaj. Inform., vol. 4, no. 1, pp. 27-35, 2015.

[16] R. D. ; I. I. Astuti, Analisis dan Perancangan Sistem Kerja, Ed.1. Yogyakarta: Deepublish, 2016. 